Impact Factor: 4.845(SJIF) Research Journal Of English (RJOE) Vol-5, Issue-2, 2020

www.rioe.org.in An International Peer-Reviewed English Journal

ISSN: 2456-2696

Indexed in: International Citation Indexing (ICI), International Scientific Indexing (ISI), Directory of Research Journal Indexing (DRJI) Google Scholar \& Cosmos.

\title{
SURFACE OF LIGHT IN AMITAV GHOSH'S SELECTED NOVELS -THE SHADOW LINES AND THE GLASS PALACE
}

\author{
Rajesh R Vijay Kumar, \\ Acharya Nagarjuna University, Department of English Guntur ,India \\ Dr Pankaj Kumar K, \\ Department of English, Acharya Nagarjuna University, India
}

\begin{abstract}
:
This paper takes into discussion the diasporas phenomena, namely, baseless nostalgia, memory and alienation in two of Amitav Ghosh's novels namely The Shadow Lines and The Glass Palace. It infers that the characters get respite from memory banks. Ghosh uses the flashback technique in order to intensify the characters' quest for identity. Diasporic literature traverses barricades in order to clinch a new selfhood. The very thought and longing for belongingness form the core to search for the original root. It refers to the rootedness namely one's home-place. One is not able to detach from the human bondage, sentiments, and love. Another element which is associated with this attachment to homeplace is 'Memory'. An immigrant never forgets one's home-place. The thread which links the past and the present is the recollection. Thus, nostalgia and memory are equally interlinked to search for one's root or belongingness. This fixation to one's home-place is the belongingness which is portrayed through the lens of recollection and flash back technique. Past always acts as a mirror in which the present has its reflections. In the Shadow Lines the glorious memories of Calcutta and Dhaka are beautifully pictured by the characters longing for their homelands. The partition of Bengal and the resultant trauma are widely depicted. The old family house stands as a wholesome framework of attachment of deep rootedness. It remains a home for the grandmother, even after partition and she always longs to see it again. In the Glass Palace, home thoughts are not something to be merely remembered as an abstract construct but represented as a cultural tool of negotiation for new cultural encounters. Thus, a new space is created through home a thought which helps in the construction of a new identity. The past is remembered not as a dead, remote period, but as flowing on, into the present.
\end{abstract}

Keywords: Reflections, partion, diasporic, rootedness, attachment 
Impact Factor: 4.845(SJIF) Research Journal Of English (RJOE) Vol-5, Issue-2, 2020

www.rjoe.org.in An International Peer-Reviewed English Journal

ISSN: 2456-2696

Indexed in: International Citation Indexing (ICI), International Scientific Indexing (ISI), Directory of Research Journal Indexing (DRJI) Google Scholar \& Cosmos.

\section{Introduction:}

Split into two parts ('Going Away' and 'Coming Home'), the novel follows the life of a young boy growing up in Calcutta, who is educated in Delhi and then follows with the experiences he has in London.However, one day he involuntarily shows his feelings when she, unaware of his feelings for her, undresses in front of him. She feels sorry for him but immediately abandons him to visit Nick's (the Price family's son, and the man who she later marries) bedroom. Tha'mma does not like Ila; she continually asks the narrator "Why do you always speak for that whore?" Tha'mma has a dreadful past and wants to reunite her family and goes to Dhaka to bring back her uncle. Tridib is in love with May and sacrificed his life to rescue her from mobs in the communal riots of 1963-64 in Dhaka.

- Tridib - The protagonist is a middle class boy who grows up in a middle-class family; he is the narrator's uncle. He is in love with May.

- Tha'mma (the narrator's grandmother) - She was the headmistress of a girls' school in Calcutta. She is a very strict, disciplined, hard-working, mentally strong and patient lady. She is that the one who wants to bring her uncle, Jethamoshai, to India to measure together with her, eventually resulting in his and Tridib's deaths by a mob in Dhaka.

- Ila - She is the narrator's cousin who lives in Stockwell, London. The narrator is in love with her, but she marries Nick.

- May - She is the Price family's daughter. She is crazy with Tridib and blames herself for his death.

- Nick - He is the Price family's son, distinguishable by his long blond hair. He wants to work in the 'futures industry'. He marries Ila during the course of the novel, but it's later found that he's allegedly having an affair. He worked in Kuwait for a brief period of time but quit his job (it is implied that he may have been fired for embezzlement).

- Mayadebi - She is the narrator's grandmother's younger sister and Tridib's mother.

The Shadow Lines (1988) may be a Sahitya Akademi Award-winning novel by Indian writer Amitav Ghosh. It is a book that captures perspective of your time and events, of lines that bring people together and hold them apart; lines that are clearly visible from one perspective and nonexistent from another; lines that exist within the memory of 1 , and thus in another's imagination. A narrative built out of an intricate, constantly crisscrossing web of memories of the many people, it never pretends to inform a story. Instead, it invites the reader to create one, out of the memories of these involved, memories that hold mirrors of differing shades to an equivalent experience.

The novel is about against the backdrop of historical events just like the Swadeshi movement, Second war, Partition of India and Communal riots of 1963-64 in Dhaka and Calcutta.

The novel earned Ghosh the 1989 Sahitya Akademi Award for English, by the Sahitya 
Impact Factor: 4.845(SJIF) Research Journal Of English (RJOE) Vol-5, Issue-2, 2020

www.rjoe.org.in An International Peer-Reviewed English Journal

ISSN: 2456-2696

Indexed in: International Citation Indexing (ICI), International Scientific Indexing (ISI), Directory of Research Journal Indexing (DRJI) Google Scholar \& Cosmos.

Akademi, India's National Academy of Letters.[2] The novel was translated by Shalini Topiwala into Gujarati In 1998.

The novel starts with an 11-year-old boy called Rajkumar running through the town of Mandalay to seek out a lady called Ma Cho. He is the last surviving member of his family and comes to Burma from India with a bright entrepreneurial spirit and a hunger for success.

As the British invasion comes to topple the incumbent regime, everyday citizens of Mandalay are able to enter the enshrined building, and it is then that Rajkumar spots Dolly, one of the princesses' attendants, and instantly falls in love with her. However, the entire Royal Family and their entourage are quickly extradited by the British and forced into house arrest thousands of miles away on the West coast of India.

Borrowing cash from Saya John, he makes the journey to India to recruit povertystricken village-dwellers into the comparatively lucrative (yet undoubtedly perilous) world of early oil-mining in Burma. Having made enough money this way, Raj kumar does what has been his dream for some time: buy a timber-yard of his own, with Doh Say as business partner.

Having built a more than modest commercial empire, Raj kumar had one piece of unfinished business: to track down the only girl he'd ever loved, Dolly. Through an Indian connection in Rangoon (Yangon), Raj kumar makes contact with Ratnagiri via Uma, and is accordingly granted an audience with the Collector and his wife over a meal that of course stiffly conforms to colonial best practice. To his surprise, Dolly is present, and after some drama, he finally persuades her to leave the family she has been exiled with, and return with him to Burma as his wife.

The second half of the novel entitled 'Coming Home' commences with the narrator narrates about his adolescence days spent with his granny and mother. It narrates the sequential events that occurred in 1962. The writer reveals about his granny and grandpa. His grandpa was an engineer with the Railway services in Burma. Their familial ancestral house was in Dhaka however after partition in 1947, they shifted to Calcutta and his granny was still associated to her house in Dhaka. The writer's father was serving in Calcutta.

May Price and Tridib were best friends. Tridib used to write letters to May. In one letter, Tridib wrote to May about a sexual encounter of an unknown person which he saw and discloses it in at length where May felt uneasy after reading it. She thought it must have been fictitious incident. It was a pornographic, obscene letter which had also upset her.

In March 1963 on one fine evening, the writer's father returned home in a pleasant mood. His mother asked him the reason of his happiness, but he simply smiled. He asked 
Impact Factor: 4.845(SJIF) Research Journal Of English (RJOE) Vol-5, Issue-2, 2020

www.rioe.org.in An International Peer-Reviewed English Journal

ISSN: 2456-2696

Indexed in: International Citation Indexing (ICI), International Scientific Indexing (ISI), Directory of Research Journal Indexing (DRJI) Google Scholar \& Cosmos.

them to wait till supper. His father had got a backing by promotion in his line of work. He had been made legal adviser in the deputy high commission in Dhaka. This news made his granny unhappy and she closed herself in her room. One fine day his granny received a letter from her sister Mayadebi with an invitation to visit Dhaka. Mayadebi was in Delhi and she made a call to his granny. Their uncle still resides in their house. It would be a come back to their familial roots. The granny received air-ticket for Dhaka on the 3rd of January 1964. She was thrilled, excited now for the first time. Tridib also got prepared to visit Dhaka with granny and May.

Where, as Ila got married to Nick Price in London. Nick had expressed that if would be fun and entertaining to have a Hindu marriage ceremony. Arrangements were already ongoing in Calcutta. Already Ila's parents were in Calcutta who are looking after the marriage preparations later both Ila and Nick had planned their honey-moon in Africa. The writer attends the dinner banquet of Ila's marriage in England. He got drunk so much that and May Price took him to her residence. He made a useless attempt to seduce, tempt her but a sound scolding, berating sent him to bed like an obedient, well behaved boy.

May Price arrives to Calcutta and the writer wanted to accompany her to show the beautiful places in the city. Meanwhile, she observed Tridib in the crowed then she ran towards him and embraced, clung him. She was given the writer's guest room to stay which looked out upstairs of the garden. The writer together with Tridib and May Price visited the Victoria Memorial and other beautiful places. May price was fascinated with the elegance, grandeur, magnificence beauty of these places. Suddenly they saw a dog lying on the roadside, almost half-dead and May Price wanted to help the animal but it was too late. She was hurt, wounded by the dog and eventually the dog was given mercy death.

Meanwhile, Nick Price and Ila had just arrived from their honeymoon. Ila telephoned the writer and it was a delightful, pleasing surprise for him. From there on the writer was in England and Ila took him to her home where Mrs. Price, the mom of Nick price, opened the door. Ila took him to the basement, underground room which they had visited in the past. It was a visit to the basement like that in Raibazar in calcutta. The writer was reminded of Tridib and other people in his life. The cellar room in the old house was the preferred popular place of kids in Raibazar, Calcutta.

On 2/01/1964,the writer together with other family members leftover for Dhaka to visit their ancestral, family trait house. They came to know that their old ancestral house was owned by a mechanic named Saifuddin who build an automobile workshop. Mayadebi was more delighted on this visit. Maya also came to know that their old uncle still lived with the motor mechanic in Dhaka because he had denied, refused to leave the house in 1947. Till then, he had been like a family member in Saifuddin's house. The news of 
Impact Factor: 4.845(SJIF) Research Journal Of English (RJOE) Vol-5, Issue-2, 2020

www.rioe.org.in An International Peer-Reviewed English Journal

ISSN: 2456-2696

Indexed in: International Citation Indexing (ICI), International Scientific Indexing (ISI), Directory of Research Journal Indexing (DRJI) Google Scholar \& Cosmos.

communal violence in Calcutta and Dhaka spread, and the stay of Mayadebi and others appears to be unsafe, risky in Dhaka. So they decided and determined to visit the house at the earliest. They took car and drove through the deserted streets of Dhaka. The writer, Robi, May Price, Tridib, Mayadebi and her sister were in the car. During the time of moving through different locations, both the elderly sisters were reminded of their childhood, tender age days and beautiful past years.

When they all entered their old ancestral house, they were stunned, shocked to see the house convert into a workshop cum garage. There were motorbikes all around for repairs and restore. On seeing the visitors, the auto mechanic Saifuddin came out to greet them. They want to know about the old man 'Ukil-babu' who was sick. Mayadebi called him 'Jetha Moshai'. And she told him their purpose of visit was to bring him back to Bengal. However, the elderly man didn't mind her words. He didn't deny recognizing them. As he had lost his healthy mind and appeared to have been bond in a time sequence. He denied, refused to leave the locality because he had failed to remember about his past. Now his present day was the only real world for him.

The driver came running to caution them that there had been trouble, worrying situation in Dhaka, and they must leave the place immediately. Mayadebi, her sister and other leave the place with a bleeding heart. On observing this, the old man rise and was put in an auto rickshaw that chased the convoy. On the way, the streets were abandoned. Only then, they saw a mob on the road side waiting for the victims, sufferers. The mob blocked the rickshaw and pulled down the elderly old man. On seeing this May Price got down to rescue the old man and Tridib was after May. He ran after May, yelling at her to stop. On seeing a white skinned European, the fanatic, extremist mob did not dare touch her but Tridib, a wheat-complexioned man from Calcutta got into their circle. Soon he become into a carcass. The narrator, Mayadebi, Ila, unable to help. The driver took them to a safe side. It was after many years that the narrator came to know about the true picture of communal riots through newspapers.

After many years of interval May price met the narrator in Delhi and she gave him a clear picture of what happened with Tridib who ran after her. She felt guilty to be the reason of Tridib death. To rescue her from the mob Tridib got into trouble. She ended by saying that Tridib's demise was not an accident but a sacrifice. Now the May price and writer were in each other's arms. The narrator was delighted because "for the glance she had given me of a final redemptive mystery". This mystery was the mystery of a true sacrifice like that of Tridib's end of life.

The writer talks of how one's power of imagination can be passed down as a kind of continuation to a real factual, solid experience of life and also reproduce or repeat experiences which are not available first hand. Through this mean the barriers created by 
Impact Factor: 4.845(SJIF) Research Journal Of English (RJOE) Vol-5, Issue-2, 2020

www.rjoe.org.in An International Peer-Reviewed English Journal

ISSN: 2456-2696

Indexed in: International Citation Indexing (ICI), International Scientific Indexing (ISI), Directory of Research Journal Indexing (DRJI) Google Scholar \& Cosmos.

the limitations of the senses can be overwhelmed and one can have open door to several experiences further the reach of time and space as Prof. Meenakshi Mukherjee refers:

Tridib had expressed him of the desire that can move one beyond 'the limitation of one's mind to other times and places, and to a place where there was no borderline between oneself and one's image in the mirror. Distance in The Shadow Lines is thus observed as a challenge to overcome through the application of imagination, fantasy and desire until space gets disappear. One of the many intricate, tricky patterns that blend the novel together is integrated of space and time in a smooth continuity.'

Truth is versatile and a combination of reality through senses and relevant and direct use of imagination would provide improve, embellish and enriched experience rather than a basic, irrational, jumbled one without the help of imagination.

'The spatial, geographical imagination and the closeness for penetrating into other lives that the writer assimilate from Tridib, enables him to be imitative, mimetic ally situated in a distinct cultural ambiance. Even though by the end of the novel undeniable important changes have taken place that undermine the simple equation between events and their written report, undermine the basis of established truth in which the trustworthiness of the representation is affirmed upon a firm knowledge of what has happened. An uncertainty about this knowledge nullifies realism as a narrative manner, mode in The Shadow Lines.'

The shadow lines is not merely about the validity and reliability of political division but how particular events and forces can merge people towards and cumulative, collective consciousness which would be scattered and often conflicting during times of casualness. This idea is examined by the narrator while expostulating; oppose the idea of his grandmother that everlasting, eternal threat can become a means of internal unification, merging.

'The Shadow Lines undoubtedly questions the idea of nationhood that is developed through the launching of wars or forcible state mechanism. The granny valorizes catastrophe that make 'people neglect that they are born this or that, Hindu or Muslim....they become a family born of the same pool of blood.'

The novel is not only about the difficulty of nationhood based on political divisions however also the unmoved silences in the lives of people who bore the brunt of the pain and agony of partition without either their choice or volition as Prof. Suvir Kaul appropriately points out;

'The novel, The Shadow Lines is an archaeology of quietness, a slow brooming away of other cobwebs of modern Indian recollection, a recurrent return to those omissions 
Impact Factor: 4.845(SJIF) Research Journal Of English (RJOE) Vol-5, Issue-2, 2020

www.rjoe.org.in An International Peer-Reviewed English Journal

ISSN: 2456-2696

Indexed in: International Citation Indexing (ICI), International Scientific Indexing (ISI), Directory of Research Journal Indexing (DRJI) Google Scholar \& Cosmos.

and gaps that imprint the sites of personal and national anguish. While the writer explores, this is no easy project, for the calmness the disclose are not incidental or accidental, but are basic of the essence of Indian modernity, certainly of the identity of the postcolonial sub continental nation - states of India and Pakistan.'

An fascinating but neglected fact about partition is that the people mind is more focused and concentrated on partition of the western side of India ignoring the east Pakistan till 1972 which was given the name of Bangladesh after the 1972 war between India and Pakistan. This alienation towards the eastern partition finds an efficient voice in the novels of Amitav Ghosh.

'Partition is the landmark between the colonial and the postcolonial, and the turbulence and agenda that marked its portion taught people at horrible fear. At the genesis of India and Pakistan lies the national agony of partition, a blow that stiffens fear into silence, and for which The Shadow Lines attempts to find a language, a process of grief, and possibly a remembrance.'

The Colonial involvement as uttered is yet to be understood at the rooted, profound, basic structural level as it not only broke open the self isolated security of India but also disclosed reluctantly to the world away from its border and one has to come to legitimate terms and conditions in integrating the past and the present as Associate professor, Mita Bose comments;

'The burden of India's colonial past appears to weigh heavily on a migrant postcolonial generation, and Ghosh seems to be constantly in search of that elusive Epiphany moment in which individuals may come to terms with their histories, thereby releasing themselves from the metaphoric and metaphysical - burden of their condition. A 'glimpse' of final redemptive mystery is all that Ghosh can, in all honesty, give us: but it is perhaps the most precious footnote that fiction can offer our fractured, fractious history.... Those crises of diaspora that are instigated in the edge of history are precedents grounded in Amitav Ghosh to accomplish predominance in novel.'

The legitimate essence and effort of the narrator is given a fair impression in the comment of Neelam Francesca Rashmi Srivastava (Lecturer in post colonial literature) who expresses on new forms of hybrid amalgam culture emerging from colonial experiences.

'Amitav 's writing is about agony to limelight the cultural syncretism of the India in crucial resistance to the historicism of patriotic disertation. Amitav's search for an alternative anthropology and history has driven him to highlight the significance of the narration. 
Impact Factor: 4.845(SJIF) Research Journal Of English (RJOE) Vol-5, Issue-2, 2020

www.rjoe.org.in An International Peer-Reviewed English Journal

ISSN: 2456-2696

Indexed in: International Citation Indexing (ICI), International Scientific Indexing (ISI), Directory of Research Journal Indexing (DRJI) Google Scholar \& Cosmos.

Creativity, imaginative attainment of Amitav 's efficiency to merge political history with the claim of art and realism is aptly mentioned by Mita bose. Amitav 's artistic taste is a fictitious embracing of political historical subtexts, and a creative analysis of both the crucial and the marginalized, framework of modern history: memory/nostalgia, migrants, nationalism/internationalism, communalism, violence. He is continually noticing for ways in which he can contribute history into fiction. The essence of research \& contemporary, advanced means of observing actuality \& accepting the idea of the latest, newness is formulated perhaps the underlying intention and core for the narrator.

Amitav 's writtings insist on a particular rare place in the postcolonial writtings that analyze and exalts the combination of postcolonial migration and nationality.

The Glass Palace' is only such newly published post colonial fiction which mainly focused on the demeanor diminished histories of how colonialism conjugate with imperialism and destroyed the lives of people transformed them according to colonial demands to such an extent that not only their traditional anchorage are uprooted leading to the turmoil and turbulence of values but also letting loose new forces like military dictatorship which control these societies today as the present status of some Islamic countries and those of African continent amply testify.

The novel starts on a very common place note of the central character Rajkumar aged eleven and recently orphaned, standing on the road to the fort of Burma 'The Glass Place' in search of livelihood to keep body and soul together. Step by step, the writer takes the reader into the life of Burmese and how it revolves around the magnificent symbol of royalty as manifested in the description of the fort.

"It's very large, much larger than it looks. It's a city in itself, with long roads and canals and gardens. First you come to the houses of officials and noblemen. And then you find yourself in front of a stockade, made of huge teakwood posts. The period of the initiation of narration is around 1885 which is casually mentioned as the year in which the German Engineer and Inventor Karl Benz unveiled the motor wagon which brings into suggestive contrast of how the west is changing its life-style and pattern of attitude and the way Burma exists though one may not call it feudal. The writer provides a graphic description of the deposition of Ruler The baw \& Queen Supayalat together with their four daughters and how they are transported to an obscure place RATNAGIRI, the southwestern part of India in Maharashtra, so that In course of time they will fade away from the public memory of the people which is proverbially short. One is shocked at the cold, diabolic calculation of colonial rulers and the way they schemed to appropriate and plunder countries with least concern or propriety to the claims of the native rulers and people. 
Impact Factor: 4.845(SJIF) Research Journal Of English (RJOE) Vol-5, Issue-2, 2020

www.rjoe.org.in An International Peer-Reviewed English Journal

ISSN: 2456-2696

Indexed in: International Citation Indexing (ICI), International Scientific Indexing (ISI), Directory of Research Journal Indexing (DRJI) Google Scholar \& Cosmos.

The system of benign kingship was substituted by an efficient method of profiteering of the natural riches while reducing royal family to a state of beggary and destitution. The occasionally allowed visitors to Royal family under the supervision and admission by the collector were shocked by the poverty, neglect and degradation they were reduced to by colonial administrators and the prophesy of the queen as to how Burma "the land of golden pagodas" will fare under colonial rulers, drained of its wealth and well-being.

"The Queen greeted them with her proud, thin-lipped smile. Yes, look around you, look at how we live. Yes, we who ruled the richest land in Asia are now reduced to this. This is what they have done to us, this is what they will do to all of Burma. They took our kingdom, promising roads and railways and ports, but mark y words, this is how it will end. In a few decades the wealth will be gone - all the gems the timber and the oil - and then they too will leave. In our golden Burma where no one ever went hungry and no one was too poor to write and read, all that will remain is destitution and ignorance, famine and despair. We were the first to be imprisoned in the name of their progress; millions more will follow. This is what awaits us all: this is how we will all end - as prisoners, in shantytowns born of the plague. A hundred years hence you will read the indictment of Europe's greed in the difference between the kingdom of Siam and the state of our own enslaved realm".

The life and fortunes of the Royal family is linked to that of Rajkumar by his glimpsing one of the child maids of Queen "Supayalat" "Dolly Sein" who travels with the royal family to Ratnagiri and stays with them when other servants leave the place in course of time.

On the other side Rajkumar evolves out under the direction of a Chinese man "Saya John" whom he come across when he was employed in a stall. Actually Saya John is a goods supplier to timber encampment for the elicitation of teak timber which is to be carried to England. He makes his affluence both by his business acuity and nexus of network between highly influential people $\&$ also the author gives a fair and powerful characterization of Rajkumar as a matured and self-made.

"He was far from good-looking, but there was something arresting about him, a massiveness of construction, allied with an unlikely mobility of expression - as though life had been breathed into a wall of slate".

He came to know that the connection of one of the local officer, named D. P, Roy is the spouse of the District Collector posted to careful keen observation of the royal family \& through the good notes of D.P,.Roy, he is made known to the wife of the Collector Ben. 
Impact Factor: 4.845(SJIF) Research Journal Of English (RJOE) Vol-5, Issue-2, 2020

www.rjoe.org.in An International Peer-Reviewed English Journal

ISSN: 2456-2696

Indexed in: International Citation Indexing (ICI), International Scientific Indexing (ISI), Directory of Research Journal Indexing (DRJI) Google Scholar \& Cosmos.

P. Dey, whom he wants to get aware with Dolly the handmaid of the queen he saw her at the age of 10. He came to know that Dolly is still not married and lives with the poverity sticken royal family and after few difficulties, he was able to marry her and take her back to Rangoon. collector dies due to his selfmade accident and Uma returns to her father's house in Calcutta. But still the friendship between Dolly and Uma continues even though the latter migrates to U.S.

Slowly the narrative shifts his focus from the royal family in Burma towards the life of Rajkumar and Dolly to whom two children were born named Neeladri and Dinu. Along with his children growth, his business prospered and in course of time he becomes one of the wealthiest Indians in Burma. The long time friend of Dolly,Uma writes to her from U.S. after an interval of twenty long years. And their relationship is resumed once again. As Uma takes active and diligent part in Indian struggle for independence by mobilizing public opinion in U.S. for which she is greatly respected in India. On her way to India she takes the pacific route and lands in the city Rangoon to see her friend Dolly and her family.both in turn go to Calcutta, along with Uma and meets the family of his brother now married and having two children Manju and Arjun. That's way the writer builds up and narrates the relation among the two families of Dolly \& the brother's family of Uma for the future purpose. On both the sides children grow up, Manju and Neeladri Raha, Neel for a short period, they meet again in Calcutta by accident and both fall in love ending up in marriage. As families of both the sides are well established and their friendship between Uma and Dolly is more cemented into their family relationship.

The writer narration, direction turns towards Doly, Rajkumar, Manju, Neel, where by Japanese forces destroyed hardwood store and were compelled until they moved to their country. In almost adverse, unsympathetic situations historian HughTinker hails as "forgotten long march" (1941), not at any time noticed in the records of antiquity past, as it wasn't led by an charming appealing head like Mao's, still the struggles continues to common public, under such severe situations. While crossing, Mannju deliberately falls into the flowing stream, as she completely loses the hope, will, desire to continue her life. Before shelling, Neil deceased, which was prior to the burning of hardwood department.

Finally, all arrived in Calcutta at Umaa's house and were accommodated. Dolly discloses her desire to go in search of her younger son dinu who was lost somewhere in Burma.after arduous she meets Dinu in Loi Kaw.

There they spend couple of days and then dolly decides to leave and enter the monastery convent at Sagaing where she turns back to her Buddhist faith which which trains the methods of wipe out suffering by undergoing transformation of personality. On the next year she dies.

In The writer Narration doesn't end but it progressed by means of Jaaya, grand 
Impact Factor: 4.845(SJIF) Research Journal Of English (RJOE) Vol-5, Issue-2, 2020

www.rjoe.org.in An International Peer-Reviewed English Journal

ISSN: 2456-2696

Indexed in: International Citation Indexing (ICI), International Scientific Indexing (ISI), Directory of Research Journal Indexing (DRJI) Google Scholar \& Cosmos.

daughter of Raajkumar who turn to College Teaching faculty , unintentionally discloses the antiquity past of Uma-Dey her great grand aunty,. Narrator intelligently intertwine the past and the present.

Which is almost half of the century, takes back the present by seeking her Uncle 'Dinu' who is on her dad's side relation. At last, finds him in "Yangon" where he is handling a small scale photo studio., appropriately named as "The Glass Palace - The Photo Studio -". It's a sort of paradoxical or sarcastic contemplation on the grandiose glass palace of Myanmar (Burmese Royalty) which became debris now. Contrary to the Studio, that also depends upon images, reflections. Although 'The Glass Palace' Shabbied images and films in public memory but still the Studio creates some effort towards framing, catching, transient memories of past. An image is an recorded evidence of antiquity and moments with memories. Then definitely THE GLASS PLACE is an indication of memories of the past grandeur of Myanmar (Burma),. Novelist concludes Dinu, Jaya accompanying the political,civic gathering of the charismatic (Burmese) chief AungSanSuuKyi., appealing, charming chief (Burmese Leader) Aung San Suu Kyi who is struggling for independence out of tyranny fascist rule of Gen. Ne.Win. Ghosh gratitudes, fighting spirit, courage from a feeble old lady who was smart in assembling, mobilizing public point of view, activating and kept the spirit of independence Alive, high., in all hardship, she has to underwent during the process, Jaaya, much motivated and fascinated by charisma of 'Aung San SuuKyi' and flashes in the following .

"The laughter is her charisma, Jaya thought. She could hear echoes of Aung San Suu Kyi's smile of her all around, in the public. Inspite of the overrun subtlety agents, the mood was neither heavier nor feared. It was a very good humored that seems very much required at odds and with the deadened City behind. Jaaya assumed the reason of huge number had pointed their faith on 'Aung San SuuKyi', and learned that herself willing to do anything that was asked of her at that very moment of time. it was impossible to behold this woman and not be half in love.'

Dinu points out in his own way of how the political outlook of charismatic Burmese leader Aung.San Suu.Kyi is defered from current political people, it autocracy, supremacy of all forms must be opposed, one must not end by ambushed, hampered political views only but also have an sufficient space for socio cultural activities, in order to attain a feel of fulfillment, balance of life .

"Because she's the only one who seems to understand what the place of politics is.... What it ought to be.. that while misrule and tyranny must be resisted, so too must politics itself... That it cannot be allowed to cannibalise all of life, all of existence. To me this is the most terrible indignity of our condition - not just in Burma, but in many other places too... that politics has invaded everything, spared nothing .. Religion, art family....it has taken over everything .. there is no escape from it...and yet, what could 
Impact Factor: 4.845(SJIF) Research Journal Of English (RJOE) Vol-5, Issue-2, 2020

www.rjoe.org.in An International Peer-Reviewed English Journal

ISSN: 2456-2696

Indexed in: International Citation Indexing (ICI), International Scientific Indexing (ISI), Directory of Research Journal Indexing (DRJI) Google Scholar \& Cosmos.

be more trivial, in the end"

The Writer makes an elaborate historical detour of the history of Myanmar 1885 to 1996 i.e around English invasion, almost a hundred years and so, writer narrates antiquity of past built, in a full speed, quickening chronological sequences, changes which took place faster and immersed gradually in social, economical structure in the society. Expansionism, desperately changed the society, sort of bounce reformation into modern forms of public structure, striking own manner of living, territorial expansion is completed its leftover to the public to choose, remnants, reorganize the lives which are often with much miserable with tribulation.

As every society will have its own share, even though no one can disagree that society is free from social and cultural catastrophe., to rectify and restore. System plays key role, in restoration of the social, cultural order for long run, keeping an lively atmosphere. Legitimate enthusiasm, intrinsic means, deadly, deeply devastated by crude colonially powers, modifying the cordial structure, supply to their requirements, avarice with mere concern this one for the essence, the sentiments of the public. Consequentially the society and public, captured in historically bonded in the sensibility, that they can't return neither to their pre-colonial continuation nor can go forward pleasantly to the destiny as the values, criterion, believes are completely meshed with indigenous and foreign ideals.

Postcolonial philosopher Homii Babbha refers, in his writings "Nation And Narration", economic \& political disputes perhaps resolved, within feasible duration allotated, commitment and loyalty of the heads, unprivileged Cultural Inheritance leftover breeched by puritan regulations for long-time to be amalgamate into a modern public cordial system, very often arching towards numerous amalgamate pattern of norms, principals and research.

The prose demands, extensive records of destabilizing, expelling role played by colonization, apart from changing the native community, however, exposing much agony, psychologically \& physically. Physical, corporeal misery, might be transitory however psychological trauma is thoroughly extorted, where wounds are lugged in some or the other part of the memories. As in the Romans Era, colonial forces, forcefully expelled, dragged, uprooted brutally and even eradicated the lives of common indigenous society by forcing them to leave their comfortable living, which is not a common migration.

Critic, 'Rukominii BhayaaNair' indicates out of her study and detailed investigation, colonialization involves dislocation.

"Colonialism had movement built into its definition : troops now the march, drastic changes in administration, large-scale transfers of goods and services and reconfigurations of political boundaries. 
Impact Factor: 4.845(SJIF) Research Journal Of English (RJOE) Vol-5, Issue-2, 2020

www.rjoe.org.in An International Peer-Reviewed English Journal

ISSN: 2456-2696

Indexed in: International Citation Indexing (ICI), International Scientific Indexing (ISI), Directory of Research Journal Indexing (DRJI) Google Scholar \& Cosmos.

Any writer who seeks to present the soul of man under colonialism, as Amitav Ghosh does in his latest novel "The Glass Palace" is therefore condemned to record the exit-ential dilemma - wherein the subject is necessarily partitioned, a bewildered imagrant never quite in focus nor contained within the frame".

\section{Conclusion:}

The novel is an ambitious and compendious one as well as all section of society. Where people are figured with in spectrum with an panoramic view of life. Movement of the personalities over three continents. Search for pattern of living, clearly portrayed by the novelist.

"Ghosh's characters, in this most capacious of his fictions, literally include both kings (Thebaw, Queen Supalayat, the Burmese princesses) and commoners (Doly, Rajkumar, Saya John, Uma) but what unites them all is the inescapable narrative of colonial displacement. Buffeted about by the gale-winds of history, these protagonists are driven from Burma to India, Malaya, Singapore and back again, repeating each time a pattern of action that Ghosh presents in his first few pages".

Compared to earlier writings of Ghosh in which he tries to recreate chronological happenings. "The Glass Palace" overwhelming exploit not only fantasy which is lavishly accomplished, as a conspective realm of human desires supported by sounding research and a sensitive thoughts.

"Ghosh is a worthy writer, not a scintillating one; and his The Glass Place is important not because it opens new stylistic or thematic doors, but because it reopens old ones so effectively. Burma at the present time is near inaccessible territory; Yet ,Ghosh's book manages to hold up before a global community of readers a historically authentic 'golden' Burma as it was - and could be again. At a time of millennial doom, when we are having to radically reconfigure our dimly remembered pasts in order to understand their effects on our chaotically disturbed present that is the novel's signal postcolonial virtue elephants, teak, pagodas and all."

\section{References:}

- Amitav Ghosh 2004.The Glass Palace, : HarperCollins, India Delhi,

- Menakshi. M 2004 Maps and mirrors -The shadow lines., - oup.Publications, New Delhi.,

- Suvil.K, Separation anxiety - The shadow lines. - oup., Page ()., New Delhi.,[ 2004]

- A.Ghosh, Mita bose-2003 Introduction -Critical perspectives., Page, Permanent block., New Delhi., Neelam srivastav . 
Impact Factor: 4.845(SJIF) Research Journal Of English (RJOE) Vol-5, Issue-2, 2020

www.rioe.org.in An International Peer-Reviewed English Journal

ISSN: 2456-2696

Indexed in: International Citation Indexing (ICI), International Scientific Indexing (ISI), Directory of Research Journal Indexing (DRJI) Google Scholar \& Cosmos.

- Ghosh 2003 Fictions of nationhood,- ; Critical perspectives., Permanent block.,New Delhi.,Page

- Ghosh Mita bose: 2003 Introduction-; Critical perspective, Permanent Block, New Delhi.

- Mavita Daiya; 2003 No home but in memory - A. Ghosh; while fighting with them., its an suicidal mission, while Arjun ,really sandwiched between his own people and imperial British.

- Critical perspectives. Permanent block., New Delhi.

- Ghosh Amitav : 2008, The Glass Palace - Ravi Dayal Publishers, Penguin, India, 